\title{
THE ROLE AND PLACE OF FOREIGN LANGUAGE COMMUNICATIVE COMPETENCE IN THE FORMATION OF PROFESSIONAL COMMUNICATIVE ACTIVITY
}

\section{Kateryna Oleksandrenko}

\section{INTRODUCTION}

This chapter considers the problems of developing of foreign language communicative competence of future specialists in international relations which has become an integral part of their professional communicative activity.

A significant expansion of intercultural interaction in all spheres of life of modern man actualizes the complex problems associated with foreign language education in general and the improvement of professional training of students of higher educational institutions in particular. In the modern Ukrainian system of higher education there are contradictions between the system of teaching foreign languages and level of requirements to the professional communicative activity of the future specialists, the absence and need for the elaboration of psychological and pedagogical concept of development of foreign language communicative competence of future specialists of international relations.

It is important to define the role and place of foreign language communicative competence in the formation of professional communicative activity which is a necessary condition for training specialists who know foreign languages and are able to get in touch with the representatives of other cultures.

\section{The concept of competence in psychological and linguistics studies}

Underlying that competences are some internal, hidden psychological new formations (knowledge, attitudes, behavior, values and relationships and so on), which later identified in the competencies, I. O. Zymnyaya ${ }^{1}$ highlights the following key competences: competence relating to the person as personality, subject of activity, communication; competence relating to social interaction and social spheres and competences concerning human activities. From these positions, she has delineated three main groups of

1 Zymnyaya, I.O. (1983). Kluchevyje competentsii - novaya paradigm rezultata obrazovaniya [The key competences as a new paradigm of the result in education]. Vyssheye obrazovaniye segodnya - Higher education today. 5, 34-42 [in Russian]. 
competencies: relating to oneself as personality, as the subject of life ; those that relate to human interaction with other people and competence relating to human activities, manifested in all its types and forms. The enumarated competencies, manifesting in behavior and activity of man, become his personal qualities, features. Accordingly, they become the competencies that are characterized by motivational and sence-bearing, relative, regulatory components, along with knowledge and experience N. Chomsky ${ }^{2}$ and W. Hutmacher ${ }^{3}$ emphasize the practical side of foreign language communicative competence. Researches conducted by N.I. Kuzmina ${ }^{4}$, A. A. Bodaliov ${ }^{5}$ became the basis for the determination of readiness for professional foreign language communicative activity as an integral personal phenomenon that implies a certain level of knowledge of a foreign language, linguisticcultural orientations and communicative skills, that is, the components of foreign language communicative competence.

Despite the high frequency of usage in modern scientific literature, the categories «communicative competence» and «communicative language competence» have not been defined yet and possess some inherent vagueness in definitions resulting in ambiguity of the conceptual field. The above mentioned statement is confirmed by the results of the analysis of a number of scientific research works, dictionaries and encyclopedias. The definition does not give a clear and unambiguous understanding of the nature of foreign language communicative competence as a personal phenomenon and mechanism of its formation.

To formulate the essential characteristics of foreign language communicative competence, it is necessary to define its place concerning the other types of competences, to consider the main functions and qualities of personality that somehow determine the development of this personal phenomenon or define them. The approach to defining the role of communicative competence in the formation of professional communicative activities based on the personal qualities, seems to be more accurate and thus it relates to humanistic values.

\footnotetext{
${ }^{2}$ Chomsky, N. (1965). Aspects of the theory of syntax. Cambridge, Massachusetts : MIT Press.

${ }^{3}$ Hutmacher, W. (1997). Key competencies for Europe. Report of the Symposium Berne, Switzerland 27-30 March 1997. Council for Cultural Cooperation (CDCC) : Secondary Education for Europe. Strasburg.

4 Kuzmina,N. (1989). Professionalizm deyatelnosti prepodavatelya $i$ mastera proizvodstvennogo obucheniya [Professionalizm of teacher's and instructor's activity]. Moscow: Vysshaya shkola. [in Russian].

${ }^{5}$ Bodaliov, A. A. (1998). Vershina $v$ razvitii vzroslogo cheloveka: kharakteristiki $i$ usloviia dostizheniia. [Apex in the development of an adult: characteristics and conditions of achievement]. Moscow: Nauka. Publ. [in Russian]
} 


\section{Different approaches to the definition of communicative competence}

The developing of foreign language communicative competence is one of the main factors in the formation of professional communicative activities.

Communicative competence is regarded as a set of formed professional knowledge, communicative and organizational skills, abilities to self-control, empathy, culture, verbal and nonverbal interaction, which is necessary in training specialists of different profiles, especially in socionomic professions. Foreign language communicative competence is understood as the ability of finding verbal and non-verbal means which are adequate to the situations of interactions and ways of formation and formulation of thought in its generation and perception in native and non-native languages.

From the point of view of personal approach, foreign language communicative competence is understood as mainstreaming of foreign language competences as a basic skill and includes willingness to exercise competence ; the experience of realization of competence in standard and non-standard situations ; subject matter competence and the object of its application; emotional-volitional regulation of process and result of competence.

From the standpoint of the systemic-structural approach, communicative language competence is a system, which includes communicative and cognitive abilities, cognitive activity, motivation, creativity and willingness to communicate in a foreign language. When considering the problem of abilities we rely on theoretical insights and research results substantiated by B.G. Ananyev ${ }^{6}$, N. V. Kuzmina7, S. D. Maksymenko ${ }^{8}$, A. K. Markova S. L. Rubinstein ${ }^{10}$, B. M. Teplov ${ }^{11}$, V. D. Shadrikov ${ }^{12}$ etc.

A significant contribution to the development of the general theory of abilities was made by B.M. Teplov. Understanding abilities as individualpsychological characteristics that relate to successful performance of this or that activity, the scholar claimed that abilities are created in the activities.

\footnotetext{
${ }^{6}$ Ananyev, B.G. (2001). O problemakh sovremennogo chelovekoznaniya [On the problems of modern human studies]. St.Petersburgh: Piter.[in Russian]

${ }^{7}$ Kuzmina, N.V. (1993). Professionalizm pedagogicheskoi deyatelnosti [Professionalizm of educational activity]. Rybinsk: NITSRM [in Russian]

${ }^{8}$ Maksymenko, S.D. (2006). Heneza zdiisnennia osobystosti [Genesis of personality realization]. Kyiv: TOV «KMM» Publ. [in Ukrainian]

${ }^{9}$ Markova, A.K ( 1996) Psikhologiya professionalizma [Psychology of professionalism]. Moscow: Znaniye [in Russian]

${ }^{10}$ Rubinshtein, S. L. (1989). Printsip tvorcheskoi samodeyatelnosti [The principle of creative activity]. Voprosy filosofii - Problems of Philosophy. 4, 88-96 [in Russian]

11 Teplov, B.M. (2004) Psikhologiya $i$ psikhofiziologiya individualnykh razlichii [Psychology and psychophysiology of individual differences] Otv. red. M.G. Yaroshevskii . Moscow: Izdatelstvo MPCI [in Russian]

${ }^{12}$ Shadrikov, V.D. (1994). Deyatelnost $i$ sposobnosti [Activity and ability]. Moscow: Logos[in Russian]
} 
This idea is based on a general thesis about the manifestation and the formation of mental properties in activities.

In the structure of communicative and cognitive abilities it is possible to distinguish several groups. The first group contains phonetic, lexical, grammatical, stylistic abilities, it ensures the absorption of language, its theoretical study: knowledge of vocabulary, learning grammar rules, logicalgrammatical structures of foreign language speech. These abilities contribute to the knowledge of the language system «language competence». The second group includes abilities that are manifested in the implementation of speech and language in the process of development of foreign language speaking activity. These are the abilities of speaking, listening, reading and writing. The third group of abilities determines the sense of language and foreign language thinking.

Communicative and cognitive abilities are realized through communicative activity that involves the steps of generating and interpreting texts on the basis of productive (speaking and writing) and receptive (reading and listening) types of speech activity in a specific situation. This gave grounds to speak about the need to develop skills related to reading, listening, speaking and writing, which must be accompanied by communicative skills, verbal and non-verbal in nature. The language is considered, in some sense, as a medium of communication and the means, which must be motivated.

The actual foreign language communicative competence consists of abilities:

keep (maintain) conversation (correspondence): on everyday topic, political issues, professional topics, the countries of the target language;

to start (be engaged in conversation), to suspend, finish, change the course (subject) of the conversation, continue a conversation in a foreign language (that is, to control the conversation);

to substantiate own statements, to persuade and to stimulate by means of the foreign language, and to express own attitude to the problem under discussion: in writing, verbally (in a particular situation);

to formulate and ask questions in a foreign language in writing, orally, within the process of reading, during listening;

reply (respond) to the question (statement) of the interlocutor in a foreign language in connection with the message;

understand foreign-language text based on visualization, to extract the necessary information: in the course of reading, during listening;

understand foreign-language text without relying on the visualization: as you read, during listening, comprehension. 
Formation of readiness for professional communication activities is essential to the training of specialists in foreign language who are able to get in touch with the representatives of other cultures. A.V. Selezneva ${ }^{13}$ refers the state of readiness to self-development conditions, intellectual and volitional, as its leading components are the desire to achieve successful self-development, to develop creativity and confidence in his/her own acmeological abilities, which can be regarded as characteristics of mental and volitional process of decision-making and conscious control of behavior, activities and status during the implementation of the decision.

A state of readiness to self-development can be considered as a holistic manifestation of inner activity of the individual in overcoming the internal contradictions and creative implementation of plans and programmes of selfactualization.

The measure of readiness for self-development is defined by the general and acmeological knowledge, skills, abilities, improving mental processes, states and personality traits, responsibility for results in self-development. Readiness is characterized by different relationships among the designated targets (cognitive - knowledge of a foreign language, axiological linguistic-cultural orientation, active - communicative skills).

Considering the willingness of the student to professional communication activities as a synthesis of a number of indicators, we defined the characteristics of different levels of development for each of the indicators of readiness, which have become the criterial basis of the study of the phenomenon of readiness of students to professional communication activities. The first (cognitive) indicator was considered in the context of the study as a different level of mastering a foreign language. Having determined the second (axology) indicator of the willingness of the students to the professional communicative activity of linguistic-cultural orientation, we mean the theoretical justification of value orientations as personal formation of the subject that characterizes the attitude to the phenomena of reality.

The state of readiness to professional communication activity can be attributed to predominantly intellectual, volitional states as its leading components are the desire to solve communicative tasks successfully, to develop creativity and confidence in ones communicative abilities, which can be regarded as characteristics of mental and volitional process of decision-making and conscious governance of behavior, activities and personal state during the implementation of solutions.

13 Selezneva, Ye.V. (2002). Obshcheniye kak sreda dlya samorazvitiya lichnosti [Communication as a means for the self-development of personality]. Moscow: RAGS [in Russian] 
Solution of a variety of communicative tasks requires constant and conscious mobilization of all efforts, based on the adequate reflection of the communicative situations and the actualization of images of the structure of the future communication actions. The condition of readiness for professional communication activities is mainly a manifestation of individual psychological characteristics and established system of communicative skills. The formation of the state of readiness for professional communication activities means the formation of a system of motives, relationships, attitudes, storage of knowledge, and skills that provide the ability to perform ones own functions in the communication process effectively. The formation of the state of readiness to foreign language communication passes as the process of optimization, that is, it is brought into line with the conditions of professional communicative activities to achieve the best results within it.

Readiness to the development of foreign language communicative competence, which is the basis for the formation of professional communicative activities, involves a communicative competence, i.e. knowledge of the linguistic material, the possession of methods, techniques and means of actualization of this knowledge in a particular situation, the skills of listening, speaking, writing in a researched language. It also implies the ability to exercise mental and cognitive activity, independence and selforganization in the solution of communicative and cognitive tasks. It is obvious that different level of required knowledge system, skills and abilities, as well as a different degree of activity and independence of the personality determines the different degree of readiness to make independent decisions and exercise independent action.

Considering foreign language communicative competence as a system, within which there is communicative and cognitive abilities, cognitive activity, motivation, creativity and willingness to communication in a foreign language, let us highlight its basic functions. In scientific literature there is no clear solution to the question about the features of communicative competence. Since communicative competence is regarded by most authors as the ability of a participant of communication to coordinate his/her language activities with the actions of communication partners according to selected targets in a specific communicative situation, the main functions are considered to be communicative - information, regulatory - communicative and emotional - communicative. Information - communication function is disclosed in the processes of transmission and reception of information by the partners in dialogue. Regulatory - communicative function is evident in the impact on the behavior of partners in the process of communication. Emotional-communicative function greatly affects the emotional state of a person greatly. 


\section{The structure of foreign language communicative competence}

Analysis of the structure of foreign language communicative competence of personality as an integrative concept enables us to formulate its main functions: information, socialization, cognitive, interpretative, integrative. Information function is an exchange of messages, opinions, ideas, solutions, that occur between communicants. Information exchange can be done with the purpose of achieving some practical goals, for the solution any problem and with the purpose of communication process, maintaining relationships between people.

The function of socialization is the formation and development of cultural skills relationships between people. This function forms our opinions, worldview, and reactions to certain events, provides entry into the society and socio-cultural environment. Cognitive function contributes to the understanding and study of the world and aims at making personal sense of knowledge, norms as a critical factor of activity. The interpretative function serves for ensuring understanding of your partner in communication act, his or her intentions, attitudes, feelings, states. Various means of communication not only reflect the events of the surrounding reality, but also interpret them in accordance with a certain system of values and political orientations. Some foreign researchers define this property of communication as interpretation function, thereby emphasizing the importance of interpretation of information, screening and lighting facts from certain positions. At the same time, this feature is often used to transfer specific methods, activities, assessments, opinions, judgments, etc. Integrative function serves as a means of combining knowledge, skills and methods of educational-cognitive activity from different disciplines into a coherent system that extends the limits of the discipline «foreign language» without loss of its qualitative characteristics and indicates a high willingness and ability to selfunderstanding, self-regulation, self-realization, the ability to use inner psychological reserve in one's professional activities.

Thus, summarizing the results of determination of elements of component parts of foreign language communicative competence and its functions, one can suggest that "foreign language communicative competence" is an integrative dynamic structural-level quality of an individual, represented by a set of communicative and cognitive abilities, cognitive activity, motivation, creativity, willingness to communication by means of a foreign language aimed at improving the effectiveness of professional communication activities.

The model of foreign language communicative competence is considered as a benchmark that simulates the structure and function of the system "society - personality - activity", and as the interpretation of the object of technologization of social, psychological, technological reality. Getting started with building a theoretical model of foreign language communicative 
competence, it is necessary to consider that foreign language communicative competence is manifested intersubject interaction. In this regard, the theoretical model should reflect the essential characteristics due to intersubject patterns of interaction based on the feedback mechanism, which changes under the influence of peculiarities of professional activity of a future specialist and social environment in which this interaction is happening and will happen.

While building the model of the development of foreign language communicative competence one can highlight the structural and functional aspects. The first of these is associated with the reflection of the systemic interrelationships of the essential characteristics of foreign language communicative competence, the second one is presupposed by the processes of intersubjective interaction in which it is implemented.

The structural and functional elements of the same system are inextricably linked. The recognition of this connection is the basis of structural-functional analysis, the principles of which are well established, particularly in studies of social phenomena and processes. The latter represent structurally dismembered integrity, in which each component element has a specific functional purpose. Minding it is very useful when modeling complex processes, especially those that are of social nature. Foreign language communicative competence is one of them. That is why along with structural and functional models we used integrative, structuralfunctional models.

It is important to note that the activities for the development of foreign language communicative competence can occur spontaneously (which does not exclude its awareness and commitment) and on the basis of professionally developed strategies and technologies in the process of formation of future specialist in higher educational establishments under the guidance of teachers. In both cases, it is legitimate to raise the question about the efficiency of this activity, that is, the extent to which the result is justified by the spent time, financial resources and other expenditures. From this point of view when building a theoretical model of foreign language communicative competence, it is advisable to use acmeological approach, which does not contradict the socio-psychological approach but rather complements it.

Functional components of the pedagogical system elaborated by N.V. Kuzmina allowed A.A. Derkach and S.F. Shcherbak ${ }^{14}$, by generalizing this theoretical result, to allocate macro components such as the gnostic, design, structural, organizational and communication in the foreign language

14 Derkach, A.A., Shcherbak, S.F. (1991). Pedagogicheskaya evristika: iskusstvo ovladeniya inostrannym yazykom [Pedagogical heuristics: the art of mastering a foreign language]. Moscow: Pedagogica [in Russian] 
activities of future specialists. All these components are found in activities aiming at developing foreign language communicative competence. Gnostic component involves awareness of the tasks of mastering a foreign language and their correlation with his/her general professional training, activities associated with the process of search, retrieval, systematization, generalization and the accumulation of new knowledge in a foreign language and on issues that have for students personal meaning. Gnostic component includes a system of theoretical knowledge required for productive foreign activities of the future specialist, as well as their abilities to productive use.

The design component includes activities associated with forecasting and perspective planning of solutions to specific problems in a foreign language (reading, listening, writing, speaking, communication in specific situations, etc.) and selection of the most rational of them, as well as the ability to anticipate and to relate education and practice. The constructive component is characterized by action selection of information (both linguistic and thematic) and compositional structure of the text, and the ability to transform it into diagrams, tables, drawings, graphs, figures, and vice versa: to build the text based on them, as well as the ability to build and rebuild their actions (verbal and non-verbal in nature) in connection with a specific situation of communication. The constructive component of foreign language communicative competence provides regularity and manufacturability of competence, thereby increasing the performance of the activities of the future specialist as a whole, in addition to its natural character, and minimizing accidents/mistakes.

Communicative component includes actions for the management and maintenance of conversation by means of foreign language on the topics studied, establishing contacts and appropriate relationship with the interlocutor (or interlocutors), as well as the ability to extract information and share it, to respond to the interlocutor (his verbal and nonverbal behavior). Communication component of foreign language activities plays a special role because, being developed in intersubjective interaction, this activity involves a high level of foreign language communicative competence.

Organizational component determines the actions to implement the plan in time and space in accordance with the agreed principles, plans, rules, and contains the ability to act on the sample and without the sample, individually and in the team ( as a leader including). Organizational component of the foreign language activities provides a link between the ideal model of foreign language communicative competence and the actual system of action of a future specialist in intersubjective interaction.

In our research, where the principles of personal and personal-activity approach are interrelated, and where competence is considered as a personality trait, we consider foreign language communicative competence 
as a structural-level quality of personality which is realized through the activities and presented as a set of communicative and cognitive abilities, cognitive activity, motivation, creativity and readiness for foreign language communication.

Foreign language communicative competence of a future specialist is a system of his identity, which developes by itself and is expressed in the willingness and ability to act on the basis of foreign language knowledge in different situations, and in the context of professional communication activities including. We noted the essential characteristics of foreign language communicative competence in its totality are expressed in motivational target, projective-constructive, social-perceptual, operational and reflexive components (Fig. 1).

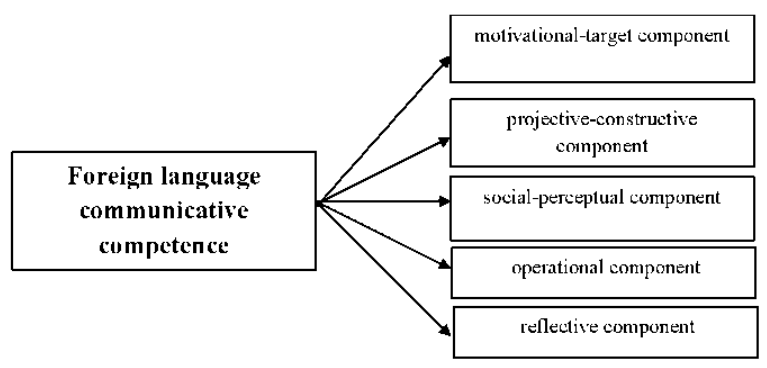

Motivational-target component provides the set of motives and internal conditions which determine, direct and regulate the process of foreign language communication. Projective-constructive component provides a practical analysis of the effectiveness of foreign language communication, forecasting the possible solutions to communication problems; updating the foreign language competence that is relevant to the purpose and situation of foreign language communication. Social-perceptual component ensures the situation/context of foreign language communication. Operational component ensures the implementation of operational plan and programme of foreign language communicative interaction through productive implementation of foreign language competencies. Reflexive component provides an adequate assessment of the deployment of the specific situation of foreign language communication and choice of possible variants of its development; it allows to understand the ways of self-improvement in the field of foreign language communication.

\section{CONCLUSIONS}

Summarizing the results of determination of elements of component parts of foreign language communicative competence, it is possible to assert that 
"foreign language communicative competence" is an integrative dynamic structural-level quality of the individual, represented by a set of communicative and cognitive abilities, cognitive activity, motivation, creativity, willingness to communication in a foreign language aimed at improving the effectiveness of professional communication activities. Analysis of the structure of foreign language communicative competence of the personality as an integrative concept allows us to formulate its main functions: information, socialization, cognitive, interpretative, integrative.

Foreign language communicative competence of a future specialist is a system of his/her identity, which expresses itself in the willingness and ability to act on the basis of foreign language knowledge in different situations, including the context of professional communication activities. The investigated essential characteristics of foreign language communicative competence in its totality are apparent in its motivational target, projectiveconstructive, social-perceptual, operational and reflexive components.

\section{SUMMARY}

Distinct and concrete presentation of the essence of foreign communicative competence as a newly established personal feature and mechanism of its development is formulated. Foreign communicative competence of the future specialist is the system of his/her personality, which may be described as self-developing and is expressed in readiness and ability to act on the basis of foreign language knowledge in different life situations the context of professional communicative activity including.

The essential features of foreign communicative competence are defined, which in their unity are expressed in its motivational - purposeful, projective - constructive, social - perceptive, operational and reflexive components, and encourage the formation of professional communicative activity of future specialists in international relations.

\section{REFERENCES}

1. Ananyev, B. G. (2001). O problemakh sovremennogo chelovekoznaniya [On the problems of modern human studies]. St.Petersburgh: Piter.[in Russian].

2. Bodaliov, A. A. (1998). Vershina v razvitii vzroslogo cheloveka: kharakteristiki $i$ usloviia dostizheniia. [Apex in the development of an adult: characteristics and conditions of achievement]. Moscow: Nauka. Publ. [in Russian]

3. Chomsky, N. (1965). Aspects of the theory of syntax. Cambridge, Massachusetts : MIT Press.

4. Derkach, A. A., Shcherbak, S.F. (1991). Pedagogicheskaya evristika: iskusstvo ovladeniya inostrannym yazykom [Pedagogical heuristics: the art of mastering a foreign language]. Moscow: Pedagogica [in Russian]. 
5. Hutmacher, W. (1997). Key competencies for Europe. Report of the Symposium Berne, Switzerland 27-30 March 1997. Council for Cultural Cooperation (CDCC) : Secondary Education for Europe. Strasburg.

6. Kuzmina, N. V. (1993). Professionalizm pedagogicheskoi deyatelnosti [Professionalizm of educational activity]. Rybinsk: NITSRM [in Russian].

7. Kuzmina N. V. (1989). Professionalizm deyatelnosti prepodavatelya $i$ mastera proizvodstvennogo obucheniya [Professionalizm of teacher's and instructor's activity]. Moscow: Vysshaya shkola. [in Russian].

8. Maksymenko, S. D. (2006). Heneza zdiisnennia osobystosti [Genesis of personality realization]. Kyiv: TOV «KMM» Publ. [in Ukrainian].

9. Markova, A. K. (1996) Psikhologiya professionalizma [Psychology of professionalism]. Moscow: Znaniye [in Russian].

10. Rubinshtein, S. L. (1989). Printsip tvorcheskoi samodeyatelnosti [The principle of creative activity]. Voprosy filosofii - Problems of Philosophy. 4, 88-96 [in Russian]

11. Selezneva, Ye. V. (2002). Obshcheniye kak sreda dlya samorazvitiya lichnosti [Communication as a means for the self-development of personality]. Moscow: RAGS [in Russian].

12. Teplov, B. M. (2004) Psikhologiya i psikhofiziologiya individualnykh razlichii [Psychology and psychophysiology of individual differences] Otv. red. M. G. Yaroshevskii . Moscow: Izdatelstvo MPCI [in Russian].

13. Shadrikov, V. D. (1994). Deyatelnost $i$ sposobnosti [Activity and ability]. Moscow: Logos [in Russian].

14. Zymnyaya, I. O. (1983). Kluchevyje competentsii - novaya paradigm rezultata obrazovaniya [The key competences as a new paradigm of the result in education]. Vyssheye obrazovaniye segodnya - Higher education today. 5, 34-42 [in Russian].

\author{
Information about the author: \\ Kateryna Oleksandrenko, \\ Doctor of Psychological Science, \\ Head of Foreign Languages Department \\ Khmelnytskyi National University, \\ 11 Instytutska Str., Khmelnytskyi, Ukraine, 29016 \\ orcid.org/0000-0001-9735-3715 \\ oleksandrenkok@gmail.com
}

